
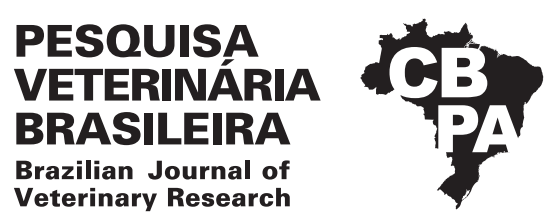

Pesq. Vet. Bras. 38(10):1949-1954, outubro 2018 DOI: 10.1590/1678-5150-PVB-5264

Original Article

ISSN 0100-736X (Print)

ISSN 1678-5150 (Online)

\title{
Evaluation of serum concentrations of cortisol and thyroxine in bitches with early-stage mammary carcinoma $^{1}$
}

\author{
Ricardo L. Salomão ${ }^{2}$, Leandro Z. Crivellenti ${ }^{2}$, Ana Paula R. Simões ${ }^{3}$, \\ Marina B.S. Brito ${ }^{3}$, Paloma E.S. Silva ${ }^{3}$, Paula B. Costa ${ }^{2,4}$, Mirela Tinucci-Costa ${ }^{3}$, \\ Aureo E. Santana ${ }^{3}$ e Sofia Borin-Crivellenti ${ }^{2,4 *}$
}

\begin{abstract}
Salomão R.L., Crivellenti L.Z., Simões A.P.R., Brito M.B.S., Silva P.E.S., Costa P.B., Tinucci-Costa M., Santana A.E. \& Borin-Crivellenti S. 2018. Evaluation of serum concentrations of cortisol and thyroxine in bitches with early-stage mammary carcinoma. Pesquisa Veterinária Brasileira 38(10):1949-1954. Faculdade de Medicina Veterinária, Universidade Federal de Uberlândia, Avenida Pará 1720, bloco 2T, Umuarama, Uberlândia, MG 38400-902, Brazil. E-mail: sofiabcrivellenti@ufu.br

In view of the fact that cancer is considered a chronic disease that can interfere with hormonal homeostasis by means of cytokines, we hypothesized that, even at early stages, mammary carcinoma is able to alter the balance of the hypothalamic-pituitary-thyroid and hypothalamic-pituitary-adrenal axes. To test this hypothesis, the serum concentrations of basal cortisol, thyroxine (T4), free thyroxine (fT4), and thyroid-stimulating hormone (TSH) were evaluated in 20 unspayed bitches that had a histopathological diagnosis of grade 1 mammary carcinoma at clinical stage I according to the World Health Organization (WHO) classification (T1N0M0). The control animals comprised 10 unspayed bitches in perfect health conditions that were matched with those with mammary carcinoma by age. No significant differences regarding the concentrations of basal cortisol, TSH, t4, and fT 4 were found between the bitches carrying early stage mammary carcinoma when compared to the control group. This suggests that, even if malignant, early-stage mammary carcinomas do not exhibit the ability to alter the concentrations of hormones produced by the hypothalamic-pituitaryadrenal or hypothalamic-pituitary-thyroid axes.
\end{abstract}

INDEX TERMS: Serum concentration, cortisol, thyroxine, bitches, mammary carcinoma, dogs, hormone quantification, mammary cancer, endocrine tests, clinics.

RESUMO.- [Concentrações séricas de cortisol e tiroxina em cadelas com carcinoma mamário em estádio inicial.] Em vista do fato de neoplasias serem consideradas doenças crônicas que por meio de citocinas podem interferir na homeostase hormonal, hipotetizou-se que o carcinoma mamário, mesmo

\footnotetext{
${ }^{1}$ Received on July 7, 2017.

Accepted for publication on March 3, 2018.

${ }^{2}$ Universidade de Franca (Unifran), Avenida Dr. Armando de Sáles Oliveira 201, Parque Universitário, Franca, SP 14404-600.

${ }^{3}$ Faculdade de Ciências Agrárias e Veterinária (FCAV), Universidade Estadual Paulista (Unesp), Campus Jaboticabal, Via de Acesso Prof. Paulo Donato Castelane s/n, Vila Industrial, Jaboticabal, SP 14884-900, Brazil.

${ }^{4}$ Faculdade de Medicina Veterinária, Universidade Federal de Uberlândia, Avenida Pará 1720, bloco 2T, Umuarama, Uberlândia, MG 38400-902, Brazil. *Corresponding author: sofiabcrivellenti@ufu.br
}

nos seus estádios iniciais, fosse capaz de alterar o equilíbrio dos eixos hipotalâmico-hipofisário-tireóideo e hipotalâmicohipofisário-adrenal. Para tal, foram avaliadas as concentrações séricas de cortisol basal, tiroxina (T4), tiroxina livre (fT4) e tireotrofina (TSH) de 20 fêmeas caninas, inteiras, com diagnóstico histopatológico de carcinoma mamário grau 1 e estadiamento clínico I segundo a classificação da Organização Mundial da Saúde - OMS (T1N0M0). Os animais controle constituíram-se por 10 fêmeas caninas inteiras, em perfeitas condições de higidez, as quais foram pareadas, por idade, com aquelas portadoras de carcinoma mamário. Não foram encontradas diferenças significativas nas concentrações de cortisol basal, TSH, T4 e fT4 das cadelas portadoras de carcinoma mamário em estádio inicial quando comparadas às controles sugerindo que, mesmo considerados malignos, ainda não apresentam a capacidade de alterar as concentrações dos 
hormônios produzidos pelos eixos hipotalâmico-hipofisárioadrenal e tireóideo.

TERMOS DE INDEXAÇÃO: Concentração sérica, cortisol, tiroxina, cadelas, carcinoma mamário, caninos, determinações hormonais, neoplasia mamária, testes endócrinos, clínica.

\section{INTRODUCTION}

Breast cancer is considered one of the worst health issues affecting women in the western world (Lacombe et al. 2013). Likewise, it is a neoplastic disease that frequently affects adult female dogs (De Nardi et al. 2009), which makes this species an excellent model for understanding the physiopathology, diagnostics, treatment, and prognostics of mammary carcinoma in humans; the most frequent forms of this disease in both humans and dogs are epithelial (carcinoma), and mixtures of epithelial and connective tissue (carcinosarcomas or mixed malignant tumors) (Ferreira et al. 2003, Lana et al. 2007).

Studies indicate that tumor size, involvement of lymph nodes, and histological grade are among the factors associated with a negative prognosis in cases of mammary neoplasia (Novosad 2003). Several authors agree that early detection and early therapeutic intervention are essential for preventing spreading of this cancer to nearby or distant sites in the body (Novosad 2003, Lana et al. 2007, De Nardi et al. 2009).

Even though bitches exhibit high mortality rates (Schneider etal. 1969) and reduced average survival time after diagnosis, mammary cancers at early stages are frequently overlooked by clinicians and tutors owing to the scarcity of research data on the early stages of this disease (Sorenmo et al. 2003).

There is evidence that other factors are involved in the progression of mammary cancer, even in early stages. The influence of hormones on the onset, maintenance, and progression of mammary tumors has been intensely studied, especially in the last two or three decades (Rutteman \& Misdorp 1993, Peña et al. 2003, Queiroga et al. 2005, Hardee et al. 2006, Illera et al. 2006, Obr \& Edwards 2012, Brisken 2013, Perry et al. 2013). Mammary cancer is a chronic disease that elicits an inflammatory response; hormones and cytokines potentially related to the occurrence of this disease include cortisol, thyroxine, and proinflammatory cytokines (Baumann \& Gauldie 1994).

From the endocrinological standpoint, and similar to what happens in other chronic diseases, changes in the balance of these hormones are speculated to mislead interpretation of hormonal tests, which could result in false positives for important endocrine diseases such as hypothyroidism and hypercotisolism (Buckingham et al. 1992, Carvalho \& Jericó 2004), and, ultimately, lead to inadequate procedures and treatments.

Therefore, since mammary carcinoma is a malignant neoplasm, we hypothesized that, even at its early stages, this disease is able to change the hormone production balance of the hypothalamic-pituitary-adrenal (HPA) and the hypothalamicpituitary-thyroid (HPT) axes.

\section{MATERIALS AND METHODS}

This experiment has been approved by the Ethics Committee on Animal Use (CEUA) of São Paulo State University (UNESP), Jaboticabal campus, SP, Brazil (protocol no. 010289/14).
Experimental groups. This prospective study included 20 unspayed bitches with a histological diagnosis of mammary carcinoma at clinical stage I according to the TNM classification of the World Health Organization. These bitches were treated at the "Governador Laudo Natel" Veterinary Hospital of FCAV/Unesp, Jaboticabal campus or at the Veterinary Hospital of University of Franca (Unifran), and were subjected to mastectomy and ovariohysterectomy $(\mathrm{OH})$. The control group (CG) was composed of 10 healthy unspayed bitches that were selected and matched by age with their counterparts in the mammary carcinoma group (MCG). All the patients were evaluated by means of clinical and laboratory exams before mastectomy and/or $\mathrm{OH}$. Animals were excluded from the CG whenever they exhibited any type of tumor, signs of metastasis in nearby or distant lymph nodes, and/or endocrinopathy within six months after the initial hormonal evaluation. Additional exclusion criteria in study were previous history of treatment with exogenous corticosteroid (or any other type or hormone replacement therapy), concomitant disease that involved thyroid or adrenal glands, pregnancy, presence of any tumors other than mammary carcinoma, and evidence of pulmonary, abdominal, and/or adjacent lymph node (axillary and/or inguinal) metastasis as assessed by radiographic, ultrasonographic or histopathological exams.

Sample collection. Before mastectomy, peripheral blood samples were collected by venipuncture of the jugular vein. A fraction of the blood was transferred to vacuum tubes containing K2-EDTA for hematological analyses; another fraction of the blood was transferred to vacuum tubes containing no anticoagulant, which were then centrifuged for 15 minutes at $800 \mathrm{xg}$ in a refrigerated centrifuge to provide serum. Serum samples were frozen at $-80^{\circ} \mathrm{C}$ for subsequent biochemical analysis, including quantification of hormones and cytokines.

Laboratory analyses. All the hematological and biochemical laboratory analyses on samples of all the patients were performed at the "Professor Dr. Joaquim Martins Ferreira Neto" Veterinary Clinical Pathology Laboratory at "Governador Laudo Natel" Veterinary Hospital at UNESP, Jaboticabal campus, SP, Brazil, and at the Clinical Pathology Laboratory of Franca (UNIFRAN), Franca/SP, Brazil. Complete blood count was performed using automated cell counters (ABC Vet - HORIBA ABX - e pocH-100 Iv-Diff - MS Diagnóstica). Serum samples were processed using commercially available kits (Reagentes - Labtest Diagnóstica) following the manufacturer's instructions in order to determine the concentrations of creatinine, urea, total protein, albumin, alanine aminotransferase, and alkaline phosphatase.

Hormonal analyses. The samples were submitted to a Brazilian veterinary endocrinology reference laboratory (Provet, Medicina Veterinária Diagnóstica, São Paulo/SP), where they were processed routinely, and the hormonal analyses were performed in duplicates. All the quality tests for these analyses were done according to the directions of the international scientific community. Cortisol, total $\mathrm{T} 4$, free $\mathrm{T} 4$ by equilibrium dialysis, and TSH were quantitated in all of the samples included in the experiment. TSH was quantified using chemiluminescence, while the other hormones were quantified using radioimmunoassay (RIA). These hormonal quantifications were carried out using commercially available solid-phase immunoassay kits. Cortisol was quantified using a kit from MP (MP Biomedicals, Orangeburg/NY, USA). Total T4 and free T4 by equilibrium dialysis were quantified using kits from IVD (IVD, Santa Ana/CA, USA). TSH was quantified using a kit from Siemens (IVD, Santa Ana/CA, USA). All of these commercial kits were validated for use in dogs; 
reference values were provided by the manufacturer or by the reference laboratory.

Statistical analysis. The data were submitted to Kolmogorov-Smirnov normality test. Comparisons between the two experimental groups were made using the Student's t-test for variables with parametric distribution, and the Mann-Whitney test for non-parametric variables (band neutrophils, eosinophils, monocytes, creatinine, ALT, UPC, and TSH). P values less than 0.05 were considered significant. The variables are presented as mean \pm standard error of the means (parametric distribution), or median with minimum and maximum interval (non-parametric variables).

\section{RESULTS}

Age and weight were used as criteria for selection of the animals for the control group (CG), which were matched with the animals of the mammary carcinoma group (MCG). The average ages were $9.18 \pm 1.8$ years in the MCG, and $7.80 \pm 2.97$ years in the $C G(P=0.1290)$. The average weights in the MCG and in the CG were $10.90 \pm 6.97 \mathrm{~kg}$ and $10.54 \pm 4.56 \mathrm{~kg}$, respectively $(\mathrm{P}=0.8834)$.

In the MCG, $40 \%$ of the bitches exhibited nodules only in the left mammary chain $(n=8), 25 \%(n=5)$ of the bitches had nodules only in the right mammary chain, and $35 \%(n=7)$ had nodules in both chains. Most of the bitches exhibited a single mammary nodule $(40 \%, n=8)$, while $30 \%(n=6)$ had 6 nodules, $15 \%(n=3)$ had 2 nodules, and $5 \%$ had 4,6 , and 10 nodules each $(n=1)$. The average diameter of the largest mammary nodule of each bitch was $1.62 \pm 1.09 \mathrm{~cm}$. Only one bitch had a nodule in the thoracic cranial mammary gland, and two bitches had nodules in the thoracic and caudal breasts. The remaining animals $(n=17)$ had nodules in the central, abdominal and/or inguinal breasts. Histological grade evaluation categorized 19 tumors as grade 1 , and 1 tumor as grade 2 (Elston \& Ellis 1991). The most frequent type of tumor according to histological classification of mammary tumors described by Misdorp et al. (1999) was tubular carcinoma (35\%, $\mathrm{n}=7)$, followed by complex carcinoma $(25 \%, n=5)$, mixed carcinoma $(15 \%, n=3)$, complex tubular carcinoma $(10 \%, \mathrm{n}=2)$, solid tubular carcinoma $(5 \%, \mathrm{n}=1)$, papillary carcinoma $(5 \%, n=1)$, and complex tubulopapillary carcinoma $(5 \%, n=1)$.

The results of the hematological, biochemical and urinary analyses of the animals of the MCG and the CG are shown in Tables 1 and 2 .

Complete blood count (CBC) results revealed that, albeit within normal values for dogs, the variables hematocrit, red blood cells, and hemoglobin were significantly reduced in the MCG when compared to the CG $(\mathrm{P}=0.046, \mathrm{P}=0.0042$, and $\mathrm{P}=0,046$, respectively). The mean corpuscular volume (MCV) was slightly higher in the MCG when compared to the $C G(P=0.0008)$. With the exception of lymphocytes, the remaining variables of the leukogram did not differ significantly between the experimental groups. Even though absolute lymphocyte counts were within normal values for dogs, they were significantly reduced in the MCG when compared to the CG $(\mathrm{P}=0.0088)$.

No qualitative or quantitative alterations were detected in the urine samples from both experimental groups. With exception of urea, the serum biochemical variables exhibited no difference between the experimental groups (Table 2). Albeit within the normal range for dogs, urea concentration in the serum was significantly higher in the MCG when compared to the $C G(P=0.0294)$.

The hormonal evaluations revealed no alterations regarding concentrations of cortisol (basal) or hormones that represent the HPT axis, namely TSH, total T4, and free T4 by equilibrium dialysis, in any of the experimental groups; all these values were within the normal range for dogs according to the reference values provided by the laboratory where these analyses were performed (Table 3).

\section{DISCUSSION}

The ability of chemical mediators such as cytokines to effect alterations on the productions and secretion of adrenal and thyroid hormones has been known for decades (Drucker \& Shandling 1985, Baumann \& Gauldie 1994). Since mammary

Table 1. Means and standard error of the means or medians (minimum-maximum) obtained for the erythrogram and leukogram of bitches in the control and mammary carcinoma groups

\begin{tabular}{|c|c|c|c|c|}
\hline & Control group $(n=10)$ & $\begin{array}{c}\text { Mammary carcinoma } \\
\text { group }(n=20)\end{array}$ & $P$ value & $\begin{array}{c}\text { Reference } \\
\text { values* }\end{array}$ \\
\hline Hematocrit (\%) & $48.73 \pm 1.81^{\mathrm{a}}$ & $42.98 \pm 1.78^{b}$ & 0.00465 & $37-55$ \\
\hline Red blood cells $\left(\times 10^{6} / \mu \mathrm{L}\right)$ & $7.27 \pm 0.33^{a}$ & $5.97 \pm 0.24^{b}$ & 0.0042 & $5.5-8.0$ \\
\hline Hemoglobin $(\mathrm{g} / \mathrm{dL})$ & $16.26 \pm 0.77^{\text {a }}$ & $14.30 \pm 0.55^{b}$ & 0.0459 & $12.0-18.0$ \\
\hline $\mathrm{MCV}(\mathrm{fL})$ & $67.33 \pm 2.94^{\mathrm{a}}$ & $71.47 \pm 2.68^{b}$ & 0.0008 & $60-77$ \\
\hline $\mathrm{MCHC}(\mathrm{g} / \mathrm{dL})$ & $33.29 \pm 2.07^{\mathrm{a}}$ & $34.04 \pm 20.18^{a}$ & 0.3833 & $31-34$ \\
\hline Total leukocytes (cells/ $\mu \mathrm{L}$ ) & $8.840 \pm 700.3^{\text {a }}$ & $8.437 \pm 777.1^{a}$ & 0.2419 & $6000-18000$ \\
\hline Band neutrophils (cells $/ \mu \mathrm{L}$ ) & $0(0-183)^{\mathrm{a}}$ & $0(0-378)^{a}$ & 0.1172 & $0-500$ \\
\hline Segmented neutrophils (cells $/ \mu \mathrm{L}$ ) & $5.701 \pm 458.2^{a}$ & $6.460 \pm 699.8^{a}$ & 0.4661 & $3600-13800$ \\
\hline Eosinophils (cells $/ \mu \mathrm{L}$ ) & $375(0-1500)^{a}$ & $273(0-1001)^{a}$ & 0.4478 & $120-1800$ \\
\hline Lymphocytes (cells/ $\mu \mathrm{L}$ ) & $2.459 \pm 362^{\mathrm{a}}$ & $1.439 \pm 181^{b}$ & 0.0088 & $720-5400$ \\
\hline Monocytes (cells $/ \mu \mathrm{L})$ & $191.5 \pm(0-510)^{a}$ & $91(0-684)^{a}$ & 0.7387 & $180-1800$ \\
\hline Platelets $\left(\mathrm{x} 10^{6 /} \mu \mathrm{L}\right)$ & $406.5 \pm 44.5^{\mathrm{a}}$ & $322.95 \pm 26.51^{\text {a }}$ & 0.0913 & $180-400$ \\
\hline
\end{tabular}

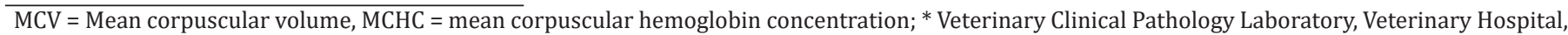

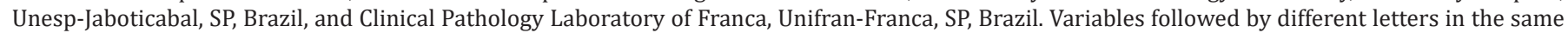
row are significantly different between the experimental groups $(\mathrm{P}<0.05)$. 
Table 2. Means and standard error of the means or medians (minimum-maximum) obtained for the biochemical (serum) and urinary variables of bitches in the control and mammary carcinoma groups

\begin{tabular}{|c|c|c|c|c|}
\hline & Control group $(n=10)$ & $\begin{array}{l}\text { Mammary carcinoma group } \\
\qquad(\mathrm{n}=20)\end{array}$ & $P$ value & $\begin{array}{l}\text { Reference } \\
\text { values* }\end{array}$ \\
\hline Creatinine $(\mathrm{mg} / \mathrm{dL})$ & $0.75(0.5-1.1)^{a}$ & $0.84(0.43-1.25)^{a}$ & 0.0862 & $0.5-1.5$ \\
\hline Urea $(\mathrm{mg} / \mathrm{dL})$ & $22.15 \pm 1.63^{\mathrm{a}}$ & $34.31 \pm 3.70^{\mathrm{b}}$ & 0.0029 & $15-65$ \\
\hline Total protein (mg/dL) & $6.48 \pm 0.31^{a}$ & $9.96 \pm 0.16^{\mathrm{a}}$ & 0.1446 & $5.8-7.9$ \\
\hline Albumin $(\mathrm{mg} / \mathrm{dL})$ & $3.14 \pm 0.08^{a}$ & $3.16 \pm 0.09^{a}$ & 0.8906 & $2.6-4.0$ \\
\hline $\operatorname{ALT}(U / L)$ & $39.00(3.9-319)^{\mathrm{a}}$ & $62.86(26.19-167.6)^{a}$ & 0.7136 & $10-88$ \\
\hline Urine specific gravity & $1.030 \pm 0.005^{\mathrm{a}}$ & $1.034 \pm 0.002^{\mathrm{a}}$ & 0.3974 & - \\
\hline UPCR & $0.19(0.02-1.17)^{\mathrm{a}}$ & $0.11(0.05-2.08)^{\mathrm{a}}$ & 0.3946 & $<0.3$ \\
\hline
\end{tabular}

ALT = Alanine aminotransferase enzyme, UPCR = urinary protein to creatinine ratio; * Veterinary Clinical Pathology Laboratory, Veterinary Hospital, Unesp-Jaboticabal, SP, Brazil, and Clinical Pathology Laboratory of Franca, Unifran-Franca, SP, Brazil. Variables followed by different letters in the same row are significantly different between the experimental groups $(P<0.05)$.

Table 3. Means and standard error of the means or medians (minimum-maximum) of the serum concentrations of basal cortisol, TSH, total thyroxine, and free thyroxine in bitches of the control and mammary carcinoma groups

\begin{tabular}{|c|c|c|c|c|}
\hline & Control group $(n=10)$ & $\begin{array}{l}\text { Mammary carcinoma group } \\
\qquad(\mathrm{n}=20)\end{array}$ & P value & Reference range* \\
\hline Basal cortisol $(\mu \mathrm{g} / \mathrm{dL})$ & $4.93 \pm 1.85$ & $5.09 \pm 2.11$ & 0.8570 & $1-4.6$ \\
\hline $\mathrm{TSH}(\mu \mathrm{g} / \mathrm{dL})$ & $0.140(0.08-0.31)$ & $0.165(0.07-0.79)$ & 0.2519 & $0.1-0.6$ \\
\hline $\mathrm{TT} 4(\mu \mathrm{g} / \mathrm{dL})$ & $1.77 \pm 0.50$ & $1.73 \pm 0.66$ & 0.8910 & $1.5-3.8$ \\
\hline fT4 (ng/dL) & $1.60 \pm 0.67$ & $1.61 \pm 0.67$ & 0.9833 & $0.82-3.65$ \\
\hline
\end{tabular}

TSH = Thyroid-stimulating hormone, TT4 = total thyroxine, fT4 = free thyroxine; ${ }^{*}$ Hormone Laboratory, Provet, São Paulo/SP, Brazil. There were no significant differences between the experimental groups $(P>0.05)$.

cancer is a chronic disease, this work aimed at assessing the possible hormonal alterations in bitches with mammary carcinoma at an early stage. None of the hormonal variables used to evaluate the afore-mentioned hormone production axes exhibited alterations in this study. These results suggest, therefore, that mammary carcinomas at an early stage are not yet able to influence the hormonal homeostasis of cortisol and thyroxine.

Integrity of the HPA axis is the major determinant of the body's response to stress (Reichlin 1993), and its response is essential for the regulation of homeostasis and survival of patients affected by chronic, critical, and inflammatory diseases (Drucker \& Shandling 1985, Sam et al. 2004). Although several studies in humans (Annane et al. 2000, Bollaert et al. 2003, Sam et al. 2004) and animals (Martin \& Groman 2004, Schoeman et al. 2007) have found a positive correlation between high basal cortisol concentrations and mortality of critical patients (Peterson et al. 1997), no data regarding hormonal homeostasis in patients with mammary cancer at an early stage has been found in the literature, which highlights the importance of the data obtained in this study.

In view of the fact that chronic inflammatory diseases such as mammary cancer are frequent in the small animal medical routine, it is important to consider that these conditions may mislead interpretation of hormonal tests. False-positive results for endocrine diseases such as hypothyroidism, hypoadrenocorticism, and hypercortisolism could lead to implementation of inadequate proceedings and treatments (Buckingham et al. 1992, Carvalho \& Jericó 2014), which could minimize or reduce the chances of determining the underlying problem, and even put the patient's life at risk.

Part of the diagnosis of endocrinopathies is done through observation of compatible clinical signs, and also by detection of hematological, biochemical, and urinary alterations related to the suspected hormonal alteration (Meuten 2012). In this regard, the fact that the blood and urinary variables evaluated were not out of the normal range for the canine species is not suggestive of any specific endocrine disease. However, it should be noted that some of these variables were significantly different between the experimental groups; therefore, they might be related to mammary cancer. The difference regarding absolute lymphocyte counts between the experimental groups could have been influenced by the stress caused by the cancer, a factor that could be intimately connected to circulating cortisol concentrations (Gilor \& Graves 2011). On the other hand, significantly lower erythrocyte-related variables in the CG could be indicative of increased production of cytokines and inflammatory interleukins able to interfere with erythropoiesis (Borin-Crivellenti \& Santana 2015), as a recent work has shown that the levels of TNF- $\alpha$, IFN- $\gamma$, IL-1, and IL-3 are significantly higher in bitches affected by mammary carcinoma, whether the magnitude of the malignancy is low or high (Machado et al. 2015).

Confirmatory diagnosis of hypercortisolism depends on the demonstration of excessive production of cortisol and/or decreased sensitivity of the HPA axis to the negative feedback provided by glucocorticoids, and the main tests used for this purpose are the ACTH stimulation test (ACTHST) and the low dose dexamethasone suppression test (LDDST), respectively 
(Gilor \& Graves 2011). The ACTHST is also used to diagnose relative or absolute adrenal insufficiency (Borin-Crivellenti 2015). Among the interleukins and necrosis factors produced by malignant neoplasms, the cytokines and inflammatory interleukins mentioned earlier, in addition to IL-10, are those with the highest amount of receptors in the hypothalamus, and binding of these molecules to their receptors stimulates the HPA axis. Therefore, these molecules are able to trigger secretion of corticotropin-releasing hormone (CRH) and, consequently, of ACTH, which ultimately results in an increase of cortisol production by the adenohypophysis (Baumann \& Gauldie 1994) that can, in turn, skew the results of the hormonal tests mentioned earlier.

The results of this pioneering study suggest that, apparently, mammary carcinomas at an early stage are unable to interfere with endocrine tests or mimic endocrine diseases that affect the axes responsible for the production of these hormones. In spite of the existence of several types of mammary cancers, this study included a significant number of bitches with early-stage mammary carcinoma, a type of cancer frequently diagnosed in small animal medicine (Lana et al. 2007), which warrants research on more aggressive and metastatic types of mammary cancers. Even though basal cortisol was chosen because it is a prognostic marker frequently used as indicative of chronic stress in patients with acute or chronic diseases (Drucker \& Shandling 1985, Bollaert et al. 2003, Sam et al. 2004), including breast cancer (Fredrikson et al. 1992, Sephton et al. 2000, Turner-Cobb et al. 2000), dynamic functional endocrine tests on the HPA axis, especially the ACTHST, are still needed to clearly determine if mammary carcinomas at an early stage in fact do not compromise the adrenal response.

\section{CONCLUSION}

Based on the results obtained in this study, we suggest that early-stage carcinomas, even if malignant, do not have the ability to alter the concentrations of the hormones produced by the HPA and HPT axes.

Conflict of interest statement.- The authors have no competing interests.

Acknowledgements.- The authors would like to thank FAPESP for financial support (\#2011/08416-6 e \#2011/11355-9), and Master's degree research financial support.

\section{REFERENCES}

Annane D., Sébille V., Troché G., Raphaël J.C., Gajdos P. \& Bellissant E. 2000. A 3-level prognostic classification in septic shock based on cortisol levels and cortisol response to corticotropin. J. Am. Med. Assoc. 283(8):10381045. <http://dx.doi.org/10.1001/jama.283.8.1038><PMid:10697064>

Baumann H. \& Gauldie J. 1994. The acute phase response. Immunol Today 15(2):74-80. <http://dx.doi.org/10.1016/0167-5699(94)90137-6> <PMid:7512342>

Bollaert P.E., Fieux F., Charpentier C. \& Lévy B. 2003. Baseline cortisol levels, cortisol response to corticotropin, and prognosis in late septic shock. Shock 19(1):13-15. <http://dx.doi.org/10.1097/00024382-200301000-00003> $<$ PMid:12558137>

Borin-Crivellenti S. 2015. Endocrinologia, p.231-272. In: Crivellenti L.Z. \& Borin-Crivellenti S. Casos de Rotina em Medicina Veterinária de Pequenos Animais. $2^{\underline{a}}$ ed. MedVet, São Paulo.
Borin-Crivellenti S. \& Santana A.E. 2015. Erythropoiesis inductor and suppressor factors: a role of hormones and cytokines. Revta Conselho Federal Med. Vet. Zootec. 66:60-66.

Brisken C. 2013. Progesterone signalling in breast cancer: a neglected hormone coming into the limelight. Nat. Revs Cancer 13(6):385-396. <http://dx.doi. org/10.1038/nrc3518><PMid:23702927>

Buckingham J.C., Smith T. \& Loxley H.D. 1992. The control of ACTH secretion, p.131-138. In: James V.H.T. (Ed), The Adrenal Gland: Comprehensive endocrinology. 2nd ed. Raven Press, New York.

Carvalho C.F. \& Jericó M.M. 2014. Adrenais, p.121-132. In: Carvalho C.F. (Ed) Ultrassonografia em Pequenos Animais. 2ª ed. Roca, São Paulo. 468p.

De Nardi A.B., Rodaski S., Rocha N.S. \& Fernades S.C. 2009. Neoplasias mamárias, p.372-383. In: Daleck C.R., De Nardi A.B. \& Rodaski S. (Eds), Oncologia em Cães e Gatos. Roca, São Paulo.

Drucker D. \& Shandling M. 1985. Variable adrenocortical function in acute medical illness. Crit. Care Med. 13(6):477-479. <http://dx.doi org/10.1097/00003246-198506000-00007><PMid:2986907>

Elston C.W. \& Ellis I. 1991. Pathological prognostic factors in breast cancer I. The value of histological grade in breast cancer: experience from a large study with long-term follow-up. Histopathology 19(5):403-410. <http:// dx.doi.org/10.1111/j.1365-2559.1991.tb00229.x><PMid:1757079>

Ferreira E., Bregunci G.C., Schmitt F.C. \& Cassali G.D. 2003. Protocol for the anatomopathological examination of canine mammary tumors. Arq Bras. Med. Vet. Zoot. 55(1):105-109. <http://dx.doi.org/10.1590/S010209352003000100017>

Fredrikson M., Hursti T., Fürst C.J., Steineck G., Börjeson S., Wikblom M. \& Peterson C. 1992. Nausea in cancer chemotherapy is inversely related to urinary cortisol excretion. Brit. J. Cancer 65(5):779-780. <http://dx.doi. org/10.1038/bjc.1992.165><PMid:1586608>

Gilor C. \& Graves T.K. 2011. Interpretation of laboratory tests for canine cushing syndrome. Topics Companion Anim. Med. 26(2):98-108. <http:// dx.doi.org/10.1053/j.tcam.2011.03.001><PMid:21596349>

Hardee M.E., Arcasoy M.O., Blackwell K.L., Kirkpatrick J.P. \& Dewhirst M.W. 2006. Erythropoietin biology in cancer. Clin. Cancer Res. 12(2):332-339. <http://dx.doi.org/10.1158/1078-0432.CCR-05-1771 ><PMid:16428469>

Illera J.C., Pérez-Alenza M.D., Nieto A., Jiménez M.A., Silvan G., Dunner S. \& Peña L. 2006. Steroids and receptors in canine mammary cancer. Steroids 71(7):541-548. <http://dx.doi.org/10.1016/j.steroids.2005.11.007> $<$ PMid:16631217>

Lacombe J., Mangé A., Jarlier M., Bascoul-Mollevi C., Rouanet P., Lamy P., Maudelonde T. \& Solassol J. 2013. Identification and validation of new autoantibodies for the diagnosis of DCIS and node negative early stage breast cancer. Intern. J. Cancer 132(5):1105-1113. <http://dx.doi.org/10.1002/ ijc.27766><PMid:22886747>

Lana S.E., Rutterman G.R. \& Withrow S.J. 2007. Tumors of the mammary gland, p.619-636. In: Withrow S.J. \& Vail D.M. (Eds), Small Animal Clinical Oncology. 4th ed. Saunders Elsevier, Philadelphia. <http://dx.doi.org/10.1016/ B978-072160558-6.50029-0>.

Machado V.S., Crivellenti L.Z., Bottari N.B., Tonin A.A., Pelinson L.P., BorinCrivellenti S., Santana A.E., Torbitz V.D., Moresco R.N., Duarte T., Duarte M.M., Schetinger M.R., Morsch V.M., Jaques J.A., Tinucci-Costa M. \& Silva A.S. 2015. Oxidative stress and inflammatory response biomarkers in dogs with mammary carcinoma. Pathol. Res. Pract. 211(9):677-681. http:// dx.doi.org/10.1016/j.prp.2015.06.011. PMid:26166177.

Martin L.G. \& Groman R.P. 2004. Relative adrenal insufficiency in critical illness. J. Vet. Emerg. Crit. Care 14(3):149-157. <http://dx.doi. org/10.1111/j.1534-6935.2004.04013.x>

Meuten D. 2012. Laboratory evaluation of thyroid, adrenal, and pituitary glands, p.479-544. In: Thrall M.A., Weiser G., Allison R. \& Campbell T. (Eds), Veterinary Hematology and Clinical Chemistry. Lippincott Williams and Wilkin, Baltimore. 
Misdorp W., Else R.W., Hellmén E. \& Lipscomb T.P. 1999. Histological classification of the mammary tumors of the dog and the cat, p.11-58. In: Ibid. (Eds), International Histological Classification of Tumors of Domestic Animals. Vol.7. 2nd ed. World Health Organization, Genebra.

Novosad C.A. 2003. Principles of treatment for mammary gland tumors. Clin. Tech. Small Anim. Pract. 18(2):107-109. <http://dx.doi.org/10.1053/ svms.2003.36625> <PMid:12831071>

Obr A.E. \& Edwards D.P. 2012. The biology of progesterone receptor in the normal mammary gland and in breast cancer. Mol. Cell. Endocrinol. 357(1/2):417. <http://dx.doi.org/10.1016/j.mce.2011.10.030><PMid:22193050>

Peña L., Silván G., Pérez-Alenza M.D., Nieto A. \& Illera J.C. 2003. Steroid hormone profile of canine inflammatory mammary carcinoma: a preliminary study. J. Steroid Biochem. Mol. Biol. 84(2/3):211-216. <http://dx.doi.org/10.1016/ S0960-0760(03)00030-X><PMid:12711005>

Perry J.K., Liu D., Wu Z., Zhu T. \& Lobie P.E. 2013. Growth hormone and cancer: an update on progress. Curr. Opinion Endocrinol. Diabetes Obesity 20(4):307-313. <http://dx.doi.org/10.1097/MED.0b013e328363183a> <PMid:23807602>

Peterson M.E., Melian C. \& Nichols R. 1997. Measurements of serum total thyroxine, triiodothyronine, free thyroxine, and thyrotropin concentrations for diagnosis of hypothyroidism in dogs. J. Am. Vet. Med. Assoc. 211(11):13961402. <PMid:9394888>

Queiroga F.L., Pérez-Alenza M.D., Silvan G., Peña L., Lopes C. \& Illera J.C. 2005. Role of steroid hormones and prolactin in canine mammary cancer. J. Steroid Biochem. Mol. Biol. 94(1/3):181-187. <http://dx.doi.org/10.1016/j. jsbmb.2004.12.014><PMid:15862964>
Reichlin S. 1993. Neuroendocrine-immune interactions. New Engl. J.Med. 329(17):1246-1253.<http://dx.doi.org/10.1056/NEJM199310213291708> <PMid:8105378>

Rutteman G.R. \& Misdorp W. 1993. Hormonal background of canine and feline mammary tumours. J. Reprod. Fertility 47(Suppl.):483-487. <PMid:8229967>

Sam S., Corbridge T.C., Mokhlesi B., Comellas A.P. \& Molitch M.E. 2004. Cortisol levels and mortality in severe sepsis. Clin. Endocrinol. 60(1):29-35. <http:// dx.doi.org/10.1111/j.1365-2265.2004.01923.x><PMid:14678284>

Schneider R., Dorn C.R. \& Taylor D.O.N. 1969. Factors influencing canine mammary cancer development and postsurgical survival. J. Natl Cancer Inst. 43(6):1249-1261. <PMid:4319248>

Schoeman J.P., Rees P. \& Herrtage M.E. 2007. Endocrine predictors of mortality in canine babesiosis caused by Babesia canis. Vet. Parasitol. 148(2):75-82. <http://dx.doi.org/10.1016/j.vetpar.2007.06.010> <PMid:17614201>

Sephton S.E., Sapolsky R.M., Kraemer H.C. \& Spiegel D. 2000. Diurnal cortisol rhythm as a predictor of breast cancer survival. J. Natl Cancer Inst. 92(12):9941000. <http://dx.doi.org/10.1093/jnci/92.12.994> <PMid:10861311>

Sorenmo K.U., Shofer F.S. \& Goldschmidt M.H. 2003. Effect of spaying and timing of spaying on survival of dogs with mammary carcinoma. Vet. Clin. N. Am., Small Anim. Pract. 33:573-596. <http://dx.doi.org/10.1016/ S0195-5616(03)00020-2>

Turner-Cobb J.M., Sephton S.E., Koopman C., Blake-Mortimer J. \& Spiegel D. 2000. Social support and salivary cortisol in women with metastatic breast cancer. Psychosomatic Med. 62(3):337-345. <http://dx.doi. org/10.1097/00006842-200005000-00007><PMid:10845347> 